\title{
O humor na literatura infantil: um estudo sobre leitura e apropriação de recursos humorísticos por crianças dos anos iniciais
}

\author{
Iara Tatiana Bonin*
}

Rosa Maria Hessel Silveira ${ }^{* *}$

\begin{abstract}
Resumo
O artigo baseia-se na articulaçáo entre o campo da literatura infantil e os estudos sobre humor. Investiga as formas como alunos dos anos iniciais apropriam-se de alguns recursos humorísticos em sua própria produção textual e imagética, após a realização de atividade com uma obra de literatura infantil, neste caso a obra $O s$ chifres de Filomena, de David Small, que incorpora elementos de humor. No estudo, aborda-se a questão do humor na literatura infantil, caracteriza-se a obra escolhida, descreve-se o trabalho realizado e interpreta-se a produçâo dos alunos, identificando nela a recriaçáo de algumas estratégias de humor. Especula-se que tanto o caráter desafiador das atividades propostas quanto as características da obra, com seu final aberto, podem ter proporcionado a grande variedade de cenários, tramas e desfechos constatada nas produçôes das crianças.
\end{abstract}

Palavras-chave: Diferença. Literatura infantil. Humorismo.

\footnotetext{
* Doutora em Educação pela Universidade Federal do Rio Grande do Sul - UFRGS. Professora do curso de Pedagogia da Universidade Luterana do Brasil - ULBRA e coordenadora do Programa de Pós-Graduação em Educação da mesma universidade. Bolsista de Produtividade em Pesquisa do CNPq.

** Doutora em Educação pela Universidade Federal do Rio Grande do Sul - UFRGS. Professora titular aposentada da Faculdade de Educação da UFRGS. Atualmente é professora permanente convidada do Programa de Pós-Graduação em Educação da mesma universidade. Bolsista de Produtividade em Pesquisa do CNPq.
} 


\section{Esboçando o cenário}

É na intersecçẫo entre dois campos temáticos principais e um campo temático auxiliar que se situa o presente trabalho. Como campos temáticos principais, situamos o campo dos estudos da literatura infantil e o dos estudos do humor, suas raízes e formas de expressão. Subsidiariamente, lançamos mão de algumas discussóes mais recentes sobre diferença e diversidade. Neste sentido, buscaremos trazer alguns elementos de cada um desses campos que nos permitam contextualizar adequadamente o estudo realizado.

A literatura infantil, como sabemos, esteve ligada, desde o seu surgimento relativamente recente, a uma concepção de criança como sujeito a ser protegido, educado e formado, preferencialmente, em instituições apartadas da sociedade mais ampla (as escolas); esteve, também, comprometida com a transmissão de valores bem definidos e com a formação de sujeitos desejáveis - morais, patriotas, trabalhadores, etc., além de ter ancorado grande parte da sua expansão no próprio uso e adoção escolar. Se, na segunda metade do século XX, a literatura infantil buscou se desligar da missão pedagógica explícita para atender a outros parâmetros, como desenvolvimento da sensibilidade, da criatividade, do gosto pela leitura, tal transformaçâo - é preciso reconhecer - não atingiu toda a produção impressa para crianças, mantendo-se, até a atualidade, a publicação constante e numerosa de livros infantis interessados em ensinar hábitos, atitudes ou conhecimentos fatuais. Por outro lado, mesmo a literatura aparentemente liberta das inspirações pedagógicas vem abrigando temas dos quais a escola também tem se encarregado, como é o caso do tema das "diferenças" e da "diversidade".

É bastante atual o incremento das discussões sobre a diversidade humana em suas formas de ser, se comportar, pensar, agir, etc. Se as questóes atinentes ao racismo, à chamada tolerância religiosa, às lutas das mulheres, por exemplo, já têm uma história, que é mais ou menos longa, por outro lado a organização e a mobilização de outros grupos (homossexuais, surdos, ciganos, etc.) em prol do reconhecimento de seus direitos de "existirem" de uma determinada forma, a ser aceita e respeitada, são bem mais recentes. Em consequência, tem-se, nos últimos anos, a emergência, no espaço educativo, do discurso que prega a necessidade de uma educaçáo para o respeito à diversidade e à pluralidade cultural (mas não apenas esta). Sem que nos detenhamos na cartografia dos diferentes elementos que, em tempos pós-modernos e de globalizaçáo, parecem 
ter se conjugado para a visibilidade e o empoderamento das diferenças e diferentes (incremento de migraçôes, estabelecimento de uma rede midiática interligando instantaneamente quase todos os pontos do globo e de uma rede de produção-consumo que transforma a diferença em produto exótico ou em nicho de mercado), importa-nos ressaltar a conexão deste fenômeno com a literatura que se oferece às crianças. Muitos são os títulos dedicados aos pequenos leitores que colocam em cena personagens gordos, velhos, indígenas, negros, surdos, cadeirantes, cegos, identificados com certas síndromes, e - embora nas últimas décadas tenha havido uma tendência de matizar seu discurso pedagógico explícito - muitos deles apresentam modelos e/ou contramodelos que, ao longo de suas tramas, vão colocando em evidência certas disposiçóes e atitudes que se deseja constituir nos leitores e que seriam capazes de, em princípio, instituir relaçôes sociais tolerantes e respeitosas.

Em pesquisa que desenvolvemos sobre a temática, reunimos um acervo de cerca de 600 obras para crianças que apresentam personagens diferentes como protagonistas, que explanam sobre uma diferença em particular ou, mesmo, sobre as "vantagens da diversidade". Com os personagens dos livros do primeiro conjunto ou sob o discurso persuasório dos segundos, os leitores dos anos iniciais vão sendo envolvidos em um conjunto de estratégias que colaboram para tornar a diferença familiar ou para problematizar as relaçóes que com ela se estabelecem. Na perspectiva teórica que orientou a pesquisa ${ }^{1}$ e inspira também este trabalho - a dos Estudos Culturais -, as diferenças não são vistas como algo que se enraíza na essência ou na natureza das pessoas, e sim como produçóes da linguagem e da cultura. As diferenças se estabelecem balizadas pelo que os grupos sociais entendem como a completude, a beleza, o equilíbrio, a inteligência, a produtividade, a racionalidade, enfim, a normalidade e a superioridade dela em relação a todos os "desvios". Tal normalidade não está intrínseca e inarredavelmente conectada a atributos naturais, ainda que frequentemente a discriminação, o desrespeito, o desprezo e a "piedade" se ancorem nessa pretensa naturalidade. É com base, pois, nessa abordagem das diferenças que é possível analisar as formas como a temática migra e se torna significativa na literatura para crianças.

Doutra parte, podemos trazer neste momento algumas rápidas reflexões sobre a temática do humor, ainda que saibamos da exiguidade da abordagem, dada a amplitude do campo, que já atraiu a atenção desde a Filosofia grega, com Aristóteles e Platão, e tem sido temática visitada por Schopenhauer, Kant, 
Bergson, Bakhtin, Propp, Freud, para citar apenas alguns autores consagrados, ao lado de abordagens mais recentes do campo da Antropologia e da Linguística. Alberti (1999), em sua abordagem do riso na história do pensamento, pontua alguns topoi da reflexão sobre o cômico e o humor, como "[...] a recorrência do caráter transgressor do riso" (ALBERTI, 1999, p. 30), a frequência com que o riso brota de "[...] jogos de palavras que evocam simultaneamente dois sentidos" (ALBERTI, 1999, p. 53) assim como a zombaria em relação ao homem (e mulher), quando considerado/a ridículo/a, evento frequente em todas as culturas, conforme Propp (1992). Também o caráter cultural e social do humor (ri-se por motivos diferentes em diferentes culturas) é sublinhado por alguns estudiosos, como Propp (1992) e Possenti (1998). Outras formas ou situaçôes em que o humor ocorre, como no riso de zombaria, na paródia, nos chistes (na conhecida abordagem de Freud), nas piadas, no recurso ao exagero e à caricatura, na utilização do grotesco (neste caso, Bakhtin é uma referência) também têm sido estudadas.

De maneira especial, para o presente artigo, os estudos de humor que lançam mão da noção de script são especialmente fecundos. Nesse sentido, Rosas (2002, p. 31) observa que

[...] um script define-se como um feixe de informaçōes sobre um determinado assunto ou situação, como rotinas consagradas e modos difundidos de realizar atividades, consistindo numa estrutura cognitiva internalizada pelo falante que the permite saber como o mundo se organiza e funciona.

Assim, podemos ter um script relativo ao que acontece numa típica aula, numa peça de teatro, num saláo de beleza, numa praça de alimentação de shopping, etc., e tais expectativas guiam nossa compreensão das situações com que nos deparamos. Raskin (1985), ao analisar textos que produzem humor, observa que, frequentemente, o efeito humorístico advém da superposição de um script em relação a outro, em oposiçóes que podem se estabelecer entre real e não real, normal e anormal, possível e impossível. Nesse sentido, o humor vincular-se-ia ao inusitado, ao inesperado, ao incongruente, à reversão de expectativas, na medida em que o novo script que irrompe numa narrativa força o leitor ou o ouvinte a rever suas predições de leitura e reinterpretar a trama que vinha sendo entendida dentro de um script inicial. 
Pois bem, estabelecidos esses três marcos iniciais - o campo da literatura para crianças, a inserção da temática das diferenças em tais livros e o campo do humor - entre os quais se situa nosso trabalho, explicitemos seu objetivo. Nos limites do presente texto, nosso objetivo é investigar de que forma alunos dos anos iniciais de escolaridade se apropriam de alguns dos recursos humorísticos de obras lidas, transportando-os para sua própria produção textual e imagética, após a realizaçáo de uma atividade com uma obra de literatura infantil que aborda a questáo da diferença e incorpora elementos de humor. Reportandonos ao escasso espaço que tem sido dado ao humor nas práticas escolares e aos também raros trabalhos de campo que têm sido dedicados ao tema no panorama acadêmico brasileiro, cremos que o atual estudo pode representar uma contribuição à discussão das conexôes entre literatura, humor e diferença, considerando, como observa lucidamente Lulkin (2007, p. 7), que "[...] investir no humor e no riso implica compreender e incorporar um fundo trágico da existência, tornando nosso discurso mais cético e não menos lúdico".

De forma a perseguir nosso objetivo, o texto está assim organizado: traremos, inicialmente, algumas reflexôes sobre a questão do humor na literatura infantil, para, em seguida, caracterizar a obra escolhida, Os chifres de Filomena, de David Small ${ }^{2}$ (2003). Posteriormente, apresentaremos um breve relato do trabalho realizado com as crianças e faremos algumas abordagens interpretativas de suas produções, com a intençáo de mapear algumas das formas de recriação, por alunos do $3^{\circ}$ e $4^{\circ}$ anos do Ensino Fundamental, de recursos do humor.

\section{Algumas palavras sobre o humor na literatura infantil}

Ainda que grande parte da literatura tradicional para crianças náo contenha elementos de comicidade ou humor (os contos de fadas, p.ex., são econômicos neste aspecto), não se pode pretender que a presença do humor nos livros para crianças seja uma absoluta novidade das últimas décadas. Duarte (2006, p. 43), por exemplo, ao analisar a extensa e fecunda obra de Lobato, destaca que

[...] o humor na obra infantil de Monteiro Lobato manifesta-se sob várias formas: nas falas do narrador, na linguagem, na exploração dos aspectos semânticos das palavras, no nonsense, na paródia, nas comparaçóes, na ironia, no cômico da situação, na inversão/subversáo da ordem, no grotesco e na construção das personagens. 
É evidente que essa multiplicidade de fontes de riso, no caso específico da obra lobatiana, não é tão facilmente encontradiça em produções de um único autor, mas certamente pode-se afirmar que a literatura infantil das últimas décadas - em especial aquela que é considerada como pertencente ao cânone - tem uma leveza que contrasta com a dominante nas décadas anteriores.

Nesta direção, Colomer (2003) afirma que a presença do humor é intensa nos livros canônicos mais recentes e que neles se encontra tanto um humor mais clássico - em que o estopim humorístico vem do estranhamento em relação ao contexto - quanto um humor mais inovador, que lança mão da paródia para subverter características de personagens tradicionais, como os monstros, as bruxas, as princesas e, inclusive, para contestar situações prototípicas de tais histórias, como o desfecho do "felizes para sempre". A autora menciona, inclusive, a frequência de uma "[...] atitude irreverente em relação à tradiçẫo do imaginário" (COLOMER, 2003, p. 340), a qual, acrescentamos nós, vem se constituindo como um veio fecundo na produção cultural contemporânea para crianças, para além dos livros de literatura infantil, como se pode exemplificar pela série dos filmes com o personagem ogro Shrek.

\section{Breve apresentação da obra e de seus recursos humorísticos}

Para situarmos a obra com a qual trabalhamos dentro das tendências contemporâneas da literatura infantil, será útil lançarmos mão da análise, feita por Colomer (2003), de um corpus representativo de 150 obras publicadas entre 1977 e 1990. A autora registra o predomínio de uma "literatura eminentemente fantástica", o que propiciaria, em muitos livros analisados, "[...] a aparição de fenômenos fantásticos para projetar uma nova luz interpretativa sobre a realidade" (COLOMER, 2003, p. 221). Tal tendência é nomeada por Colomer como "fantasia moderna" e assim ela a descreve:

O desenvolvimento da fantasia moderna supôs a criaçấo de novos imaginários de ficção a partir de diversos caminhos, associados majoritariamente ao humor: a alteração da vida cotidiana dos personagens ao irromperem elementos fantásticos, a exploração especulativa sobre o funcionamento ou consequências de fenômenos e mundos possíveis, a desmistificação dos elementos fantásticos tradicionais e o jogo metaliterário 
sobre as regras da construção narrativa. (COLOMER, 2003, p. 223).

Pois bem, é dentro desse leque de obras que podemos situar Os chifres de Filomena (SMALL, 2003), obra que conta a divertida história de uma menina que, ao despertar certa manhã, encontra um par de chifres em sua cabeça. Tal metamorfose provoca uma série de fatos inusitados e expóe variados ângulos da experiência com a diferença. Vale marcar no livro a presença de dupla narrativa - a verbal e a imagética -, de tal forma entrelaçadas, que o texto verbal não se manteria coerente se fosse privado da narrativa imagética. Colomer (2007, p. 93) observa que, se tradicionalmente, a "[...] ilustração e o texto caminhavam em planos paralelos", uma boa parte dos livros infantis atuais "[...] incorpora a imagem como elemento constitutivo da história, de maneira que os dois - texto e ilustração - complementem a informação" (COLOMER, 2007, p. 93).

O elemento fantástico já aparece na primeira frase do texto: "Quinta-feira Filomena acordou e viu que tinha criado chifres" (SMALL, 2003), enquanto, na ilustração, a protagonista aparece numa visão frontal, ocupando o centro da imagem, tateando com expressão de surpresa os enormes chifres em sua cabeça. O script ficcional e fantástico se superpóe ao do cotidiano doméstico, e este último é delineado em especial nas ilustraçóes, nas quais Filomena aparece, na primeira cena, deitada na cama, cercada de brinquedos e objetos - bonecas, bichos de pelúcia, livros, lápis e pincéis, acessórios de uso pessoal, num típico quarto de menina de classe média.

O deslizamento entre os dois scripts prossegue nas ilustraçôes seguintes, que destacam as dificuldades iniciais da personagem para vestir-se e para passar pela porta do quarto. Na sequência, ela aparece escorregando pelo corrimão da enorme escadaria de sua casa e, como ainda não está habituada aos chifres, acaba presa ao lustre fixado no teto. $\mathrm{Na}$ ilustração, vemos as expressóes de espanto dos personagens adultos e, em particular, o desmaio da máe de Filomena evento que, aliás, é reiterado ao longo da trama, e poderia ser considerado, sob inspiração de Alberti (1999), como um tipo de "queda cômica", recurso largamente utilizado para provocar o riso. Vale ressaltar, ademais, que a mãe de Filomena é apresentada de maneira caricatural: uma senhora bem vestida e adornada com joias, com vestidos que delineiam os contornos de um corpo gordo; sobre esse aspecto, vale relembrar as observações de Propp (1992), que 
aponta o fato de que o personagem gordo tem sido tratado como um dos personagens cômicos preferenciais nas obras de literatura.

Os acontecimentos narrados vão constituindo uma diferença específica (a presença dos chifres em uma menina) como algo que gera alguns contratempos na execução de suas açóes cotidianas, embora seja necessário observar que os apêndices animais não a constrangem, não a envergonham e não se configuram propriamente num problema. Já para alguns adultos, notadamente o pai, a mãe, o diretor da escola, os chifres são algo que demanda intervenção urgente, e, por isso, aqueles buscam amparo no saber médico e psicológico. Já outros personagens, também adultos, tal como a copeira e a cozinheira, divertem-se, encontrando distintas utilidades para a novidade no corpo da menina: "Filomena entrou na cozinha. Lúcia, a copeira, aproveitou e pediu para secar uns panos" (SMALL, 2003). Na ilustração que compóe a mesma página, Filomena, sentada, folheia um livro, enquanto a copeira sorridente estende panos de prato nos chifres da menina. Na cena seguinte, Filomena aparece no centro do quadro, comendo uma rosquinha, enquanto a cozinheira pendura outras em seus chifres e lhe sugere: "vá para o jardim dar comida aos passarinhos" (SMALL, 2003).

Entram em cena, em certos momentos, alguns "especialistas", que buscam explicar o acontecimento inusitado. Assim, em uma das ilustraçóes se pode ver um velho homem, com um estetoscópio no ouvido, um aparelho de medição de pressão em uma das mãos e diversos pirulitos no bolso. O texto informa: "O médico apertou, e escutou, e coçou o queixo. Não conseguia entender" (SMALL, 2003). Ainda em outra passagem, surge o diretor da escola, figura caricatural, com feições severas, grandes óculos, guarda-chuva nas mãos, trajando um longo casaco. Reza o texto correspondente: "O diretor da escola olhou Filomena com cara de mau, mas náo conseguiu arriscar um palpite" (SMALL, 2003). Além dos personagens que representam, de certa forma, o saber científico e/ou autorizado, a narrativa traz a presença do objeto livro, como depositário de um detalhado conhecimento, na passagem em que o irmáo de Filomena recorre à enciclopédia para nela buscar uma explicação plausível para o fenômeno. A ilustração mostra-o cercado de livros abertos e afirmando que "agora Filomena era um tipo raro de alce" (SMALL, 2003). É também o irmão de Filomena que, atendendo aos apelos da mãe, telefona para um chapeleiro. A solução planejada - criar um chapéu amplo o bastante para esconder os chifres - é desencadeadora de diversas situaçóes cômicas, marcadas de modo especial pelo exagero no estilo de vestir do chapeleiro, na quantidade 
de tecidos estendidos no chão para a fabricação do chapéu e na efetiva criação do chapéu para Filomena. Note-se que, conforme Propp (1992), o exagero é um dos recursos utilizados para provocar efeitos cômicos. Nas cenas, apresentadas ao estilo de uma narrativa em quadrinhos, exploram-se elementos verbais interjeiçōes como "Voilă", quando a obra é mostrada, "bravo, bravíssimo", num veemente aplauso dos chapeleiros, a onomatopeia "póim!", para indicar o desmaio da mãe - e elementos imagéticos cômicos, como o absurdo chapéu criado, com mesclas de cores, estilos e detalhes grotescos, tal o volume que é necessário para cobrir os longos chifres. Vê-se, assim, como, nessas e em outras partes da história, exploram-se certas situações inusitadas que tornam mais jocosa a narrativa.

Já no desfecho, tudo indica que haverá uma retomada do script do cotidiano: "Na 6a feira, ao acordar, Filomena não tinha chifres. Quando ela apareceu para o café, todo mundo ficou feliz vendo Filomena normal..." (SMALL, 2003). A ilustração desta sequência mostra a figura da mãe, de pé, com um largo sorriso na face e braços abertos para acolher a menina. $\mathrm{Na}$ página seguinte, o texto verbal informa apenas: "Mas aí ela entrou na sala..." (SMALL, 2003), informação que se complementa com a ilustração, na qual a personagem irrompe, com um amplo, pomposo e colorido... rabo de pavão. A cena se torna cômica, tanto porque podemos nos deliciar com o espanto dos demais personagens, todos atônitos, quanto porque as expectativas do leitor (de retorno à normalidade e de um "final feliz", sem marcas inusitadas no corpo da protagonista) são quebradas.

É importante observar também que o narrador onisciente se exime de quaisquer interferências explicativas ou moralistas no desenrolar do texto escrito, tâo ao gosto dos livros infantis que abordam questôes como a diferença. $\mathrm{O}$ texto narrativo escrito se atém prioritariamente à apresentação das açóes principais do enredo e à reprodução de algumas falas dos personagens. Também a ilustração com um acentuado caráter descritivo e um gosto nostálgico - captura a atenção do leitor. Vale acrescentar que, nesta obra, alguns personagens que acompanham o desenrolar da narrativa são apresentados apenas nas ilustraçôes, como ocorre com o gato e com o cachorro da casa - espectadores e participantes das várias cenas, os quais parecem refletir o estado de espírito de Filomena: eles não chegam a se assustar com os chifres, divertem-se com as estripulias da menina, estranham a presença do diretor ou os desmaios da máe, etc. 


\section{Um pouco sobre o trabalho com o livro}

O desenho metodológico da pesquisa previa o trabalho, em turmas dos anos iniciais de escolas públicas, com algumas obras escolhidas do acervo maior, atendendo aos objetivos da investigação, entre os quais estava o de estudar as formas como alunos dos anos iniciais negociavam o significado de alguns destes textos com suas experiências anteriores, verificando a produtividade de determinadas estratégias textuais e imagéticas. A escolha das obras para trabalho nas sessôes pautou-se em sua originalidade, na variedade de "diferenças" focalizadas e na adequação do texto ao nível de compreensão dos alunos, considerando-se que os livros eram lidos, mostrados e discutidos, mas náo havia um exemplar disponível para cada aluno naquele momento.

A partir do entendimento, corrente na literatura especializada em pesquisa com crianças, de que frequentemente meninos/as têm dificuldade em expressarem verbalmente e de forma articulada julgamentos de valor e percepções mais sofisticadas, optamos por realizar - após a leitura e discussão das obras - atividades variadas de expressão (textual e imagética) que incorporassem alguns elementos do livro estudado. No caso do livro Os chifres de Filomena (SMALL, 2003), sua escolha se deveu ao fato de que - ao figurar a diferença em uma personagem humana cuja "distinção" é inusitada e contém um caráter lúdico acentuado - o livro foi julgado como capaz de deflagrar produçôes interessantes em relação à problematização da questáo da diferença. Nas sessões com o livro, foi feita uma leitura expressiva inicial, mostrando-se as ilustraçôes aos alunos a cada página, entremeada por comentários e perguntas das crianças e das professoras pesquisadoras. Após esta conversa, as crianças receberam uma folha de papel com o seguinte enunciado (trabalho 1):

Em outro dia, Filomena apareceu com mais uma novidade, mas ela estava em outro lugar: escola, shopping, parque, praça, praia, supermercado, posto de saúde. Imagina o que aconteceu. O que as pessoas disseram? Como Filomena se sentiu? Desenha e escreve contando sobre isso.

Todo um trabalho de motivação e acompanhamento do trabalho em aula foi feito pelas professoras pesquisadoras e, eventualmente, pela professora de classe. Em uma das escolas, a docente solicitou, após uma retomada em aula 
da obra, a elaboração de um texto curto (trabalho 2), que desse continuidade ao seguinte enunciado:

Filomena apareceu para o café, todo mundo ficou muito feliz vendo que ela estava normal... Mas aí ela entrou na sala, e apareceram as penas de pavão em seu corpo...

São alguns exemplos dessas duas produções - o desenho acompanhado de um breve texto escrito (trabalho 1) e um texto escrito mais elaborado feito posteriormente ao dia da exploração (trabalho 2) - que são aqui analisados.

\section{As crianças recriam a protagonista e sua diferença}

Um primeiro aspecto a ressaltar, das produçôes textuais e imagéticas das crianças, é a frequente manutenção do tom humorístico constante da narrativa literária, e para isso elas recorrem a recursos variados de humor, tais como a quebra de expectativa do leitor, a construção de cenas que exploram o inusitado e o ridículo, etc.

Destacam-se inicialmente alguns textos ${ }^{3}$ produzidos por crianças a partir do trabalho 2, prosseguindo a frase: "Mas aí ela entrou na sala, e apareceram as penas de pavão pelo seu corpo..."

...Entäo Filomena foi disputada, e uma estilista famosa de penas pegou ela, tingiu as penas, uma de cada cor. Filomena ficou famosa, viajava para tudo o que é lugar: Austrália, China, Estados Unidos, pelo mundo inteiro, e adorou.

...Então Filomena foi convidada para ir para um zoológico para fazer um comercial de tevê dos pavóes e cada dia eles chamavam porque ela virava cada animal em cada dia... E sua mãe não desmaiou mais.

Nos dois casos, a diferença da personagem é mantida no desfecho das histórias e, ao invés de configurar-se como problema para a personagem, proporciona-lhe visibilidade, fama, mobilidade, oportunidades profissionais. Em tais casos, as crianças produzem uma narrativa humorística sobrepondo dois scripts, o de uma menina que um dia acorda diferente e o de uma celebridade que viaja para diferentes lugares e que aparece na mídia. Assim, o inesperado 
fato de terem nascido penas na protagonista leva a outro resultado: o de ela se tornar famosa exatamente pela sua diferença.

Também se podem ver, nas produçóes, algumas situaçóes em que a protagonista aprende com a experiência da diferença ou a utiliza em seu favor:

Filomena se estranhou o dia inteiro e no outro dia ela virou uma mosca e a mãe tinha comprado uma raquete elétrica, ela viu e começou a gritar e se escondeu no porão ai dormiu lá e acordou com uma cara de camaleão e assim ela começou a comer coisas estranhas..

Ela foi dormir e depois que ela acordou estava com uma tromba e com um rabo de coelho. Ela foi para a escola e estava brincando de pega-pega e conseguiu pegar todas as crianças com a sua tromba.

Então Filomena foi para cama e voltou a dormir, quando acordou estava normal, mas quando foi para a piscina apareceram pés de pato, quando foi para dentro de casa sua máe viu os pés de pato e desmaiou, e seu pai teve que levar ela em um hospicio para tratar os desmaios dela. Então, no outro dia, Filomena acordou com dentes de coelho e só ficou gastando eles na madeira e comendo cenoura.

Os exemplos trazem, no olhar das crianças, algumas dificuldades provocadas pelas novas transformaçóes (fugir para não ser confundida com outros insetos e ser morta) e possibilidades (alcançar mais facilmente os colegas na brincadeira) que se apresentam para a protagonista. Nestas produçōes textuais, destaca-se ainda a articulação entre diferentes conhecimentos: os dentes de Filomena, tal como os dos roedores, precisam ser gastos porque estáo sempre em crescimento; a cenoura é vista como alimento constante da dieta dos coelhos; a tromba é usada, pelos elefantes, para alcançar as coisas; o camaleão é um animal com aparência mutante, etc. Chamam a atenção, também, as relações de coerência entre os elementos inseridos para a composição das cenas, nas quais, inclusive, se buscam outros scripts: "quando foi para a piscina apareceram pés de pato", por exemplo.

Nos desenhos produzidos pelas crianças (trabalho 1), também se exploram alguns recursos humorísticos interessantes. A surpresa proporcionada pelas metamorfoses no corpo da protagonista se expressa, nas imagens, em 
expressōes fisionômicas dos demais personagens, por exemplo. Assim, em um dos desenhos, Filomena aparece com grandes asas de borboleta, e seus pés não tocam o chão. Ao lado dela, uma figura feminina (supostamente a máe), posicionada sobre um banco, sorri para a menina. A atitude do pai e do irmão é de espanto, demonstrado pelo formato oval da boca, pelo traçado do cabelo (em pé, no caso do menino) e pela posição das mãos (em torno do rosto, no caso do pai).

Um segundo desenho coloca em cena o inesperado, quando Filomena aparece na praia, com enormes chifres que se sobressaem na parte superior do desenho. $\mathrm{Na}$ extremidade inferior, está o mar, e se podem ver baldes, pás de brinquedo e um castelo de areia no primeiro plano. Ao lado da protagonista, estão outras meninas, todas com balóes de fala com pontos de interrogaçáo e reticências. Além das expressóes faciais que indicam espanto, verifica-se o uso de recursos das histórias em quadrinhos, possivelmente do repertório da jovem leitora.

Um terceiro desenho, no qual também se exploram recursos de humor, mostra Filomena de pé no centro do quadro, e sua imagem toma toda a dimensão vertical de um edifício, identificado pela palavra escola; à direita e à esquerda da personagem, veem-se um menino e uma menina, sentados em classes escolares. Ao fundo, está a lousa, um ícone escolar, e a cena toda se compóe de elementos plausíveis e não plausíveis, o que também produz efeitos humorísticos.

Observam-se ainda, neste rol de produçôes de crianças, algumas que buscam retomar o script dos contos tradicionais, encontrando soluçóes bem humoradas para a questão da diferença. Nesta direção, alguns desenhos "solucionam" o problema causado pela diferença com a inserção de personagens novos, também diferentes. Em uma dessas produçóes, Filomena aparece sorridente, passeando em um shopping (este, identificado pela própria palavra), com seus chifres ocupando toda a extensão superior do desenho e, no braço direito, trazendo uma sacola de compras. Ao fundo, à esquerda, um menino apresenta expressóes de surpresa marcadas no formato da boca e na mão em frente ao rosto. Ao lado dele, uma fala lhe é atribuída: "Ô, meu, essa menina é esquisita, Ave Maria!". Já à direita de Filomena, uma menina assustada, também com uma sacola de compras, diz: "Essa menina é estranha, cruz credo". Já um menino com longas orelhas e nariz em formato de tromba sorri e diz: "Essa menina faz o meu tipo". Na parte inferior do desenho, a legenda esclarece sobre 
o novo "personagem diferente", informando que ele tinha orelhas de cachorro e tromba de elefante.

A estratégia de restabelecer a "normalidade" a partir da contiguidade com outros "estranhos" é também acionada em outro desenho, no qual Filomena é retratada, sorridente e trajando um longo vestido azul, ao lado de um menino que veste camiseta e calça cor de rosa: ambos possuem chifres. No alto da página, então, se pode ler: Filomena e seu namorado.

Já em alguns textos escritos, observa-se que a criança propóe hipóteses de açôes e faz com que os personagens as experimentem, o que nem sempre produz o efeito desejado, como se vê a seguir: "então Filomena pediu a mãe para cortar e a máe concordou, mas em 10 minutos crescia novamente e ela colocou o rabo de pavão na água morna e depois cortou de novo, não deu certo e em 1 minuto cresceu novamente".

Em outro texto, a criança mescla o script fantástico (da narrativa literária) ao plausível (da experiência cotidiana), encontrando uma explicação para as transformaçôes no corpo da personagem: "então Filomena achou que estava se transformando num paváo, ela tentou cortar, ela perguntou para os pais e para os amigos, mas ninguém sabia. Ela tentou procurar na internet mas não achou nada, mas aí ela se lembrou que penas de pavão tinham grudado nela". Note-se que, neste caso, ocorre uma virada lógica - Filomena pensou que estava se transformando num paváo, mas lembrou a seguir que as penas haviam grudado no corpo nela. O problema gerado se resolve quando o fato inusitado é explicado, num desfecho inesperado, porém verossímil. Observa-se ainda que a busca de uma explicação para o surgimento das penas de pavão se realiza com recursos que parecem estar ao alcance da criança: o diálogo com os pais, a consulta aos amigos, a busca na internet.

$\mathrm{Na}$ mesma direçáo, o texto de outra criança mostra, no desfecho, que tudo não passou de um sonho da menina (seria a utilização de um topos frequente na literatura - o fantástico se resolve, porque faz parte do sonho do protagonista?). ${ }^{4}$ Noutro texto, as transformaçóes ocorreram quando Filomena foi ao Zoológico, e seu corpo apresentou semelhanças com os animais que ela observava; no entanto, "depois que ela voltou para casa, nunca mais virou nada".

Um recurso utilizado, em especial nos desenhos, é a inversão da perspectiva de gênero: em três casos, Filomena aparece como menino, o que pode decorrer da identificação do autor do desenho com a personagem. 
Observe-se que os textos imagéticos lançam mão de recursos humorísticos. Em um deles, o protagonista é Bobi, posicionado no centro do quadro e em primeiro plano; ao seu lado, está João, desenhado em proporçôes menores, mas ambos possuem chifres, e apenas Bobi exibe um rabo de pavão. Os dois personagens parecem ter expressóes faciais irônicas. Em outro desenho, produzido também por um menino, o protagonista aparece em primeiro plano, com um sorriso na face e chifres na cabeça, enquanto a seu lado está outro menino, desenhado em tamanho menor e sem nenhuma marca de diferença. Na parede ao fundo, exibe-se a fotografia de outro personagem, também com chifres; no caso, a comicidade é reforçada pela escolha dos nomes - Buli, Boli e Boláo, que sugere proximidade, trocadilhos, jogos de palavras, táo ao gosto do humor infantil.

Pode-se observar, em alguns casos, que as crianças compõem repertórios de significados "negociando-os" com outras produçôes a que têm acesso, como os programas de televisão, por exemplo.

Filomena ficou apavorada com o que viu. No dia seguinte acordou com um rabo de crocodilo, pés de coelho, orelhas de burro, nariz de bruxa e as costas estavam com escamas de peixe. Resolveu ir para uma clínica, do Doutor Castanho, e ele disse que ela era uma mutante!

Vale dizer que Dr. Castanho era um dos personagens de uma novela da Rede Globo exibida na ocasião em que foram realizadas as atividades nas escolas. O médico em questão era protagonista de cenas em que "dava aulas" sobre as manifestaçóes da diferença em sujeitos esquizofrênicos, por exemplo. Ele corporificava, nesta produção televisiva, os discursos médico e científico; em sua clínica, os pacientes eram tratados e, em certa medida, "normalizados". Talvez por essa razão, ele tenha sido lembrado pela criança para diagnosticar as mudanças corporais da personagem e colocá-las sob controle.

Um último destaque sobre as produçóes das crianças diz respeito às referências diretas feitas ao conflito central da obra literária - muitos textos afirmam que Filomena vai dormir e acorda diferente (como ocorre no livro), mas com outras marcas corporais a cada amanhecer: chifre de unicórnio (este, um elemento do repertório fantástico), chifres de boi, concha de caracol, rabo de macaco, rabo de jacaré, cara de cavalo, asas de passarinho, asas de borboleta, orelhas de elefante, orelhas de burro, orelhas de macaco, nariz de girafa, nariz 
de bruxa, tromba de elefante, boca de rinoceronte, pés de coelho, unhas de leão, escamas de peixe.

Certas produçóes infantis afirmam, tal como na narrativa literária, que a menina gosta do que vê ou que se diverte com as partes de animais que nela se incorporam. Informam também que a mãe desmaia e buscam amparo na voz autorizada de especialistas para ajudar a explicar o acontecimento inusitado. Além disso, a ideia de tornar os chifres úteis, que na narrativa do livro é marcada pela cena da copeira, pendurando os panos de prato, por exemplo, aparece também nas produções das crianças: "Filomena ficou com asas de abelha e ferrão de abelha, e ficou muito útil e fez entregas de pizza para o tio dela e também ficou muito amiga dos passarinhos da cozinheira"; "...então Filomena ficou em casa e ajudou a tirar o pó das estantes e no outro dia apareceu com tromba e ajudou a regar as flores"; Filomena "...alimentou os passarinhos"; "...ajudou a arrumar a casa", "...o rabo de pavão também serviu para tirar o pó dos móveis", "...o rabo de cavalo serviu para tirar as teias de aranha". A utilidade daquilo que, na protagonista, a identifica com certos animais faz lembrar também a conhecida crônica de Carlos Drummond de Andrade 5 , na qual o autor satiriza as relaçóes - de utilidade ou inutilidade - estabelecidas com os diferentes animais pelos homens.

Por fim, as produçóes textuais das crianças mostram uma variedade de significados e de posicionamentos em relação às diferenças. Em alguns casos, as crianças manifestam o desconforto causado pelas mutaçóes da personagem ou fazem alusões ao riso de zombaria - cuja frequência chamou a atenção de Propp (1992), que a ele dedicou várias páginas de sua obra sobre comicidade -, como nos exemplos a seguir:

Ela foi passear um pouco e todo mundo olhava para ela, foi sentar um banco e pensou: por que eu? Virei uma parte de animal e eu não gosto de ser animal.

Então foi no Shopping com o rabo de pavão e todo mundo olhou para ela e acharam estranho e os pais ficaram envergonhados...

Então Filomena voltou para a cama e dormiu. E depois ela estava a mesma coisa e ela foi para a escola e os colegas dela riram.

Então Filomena foi para a escola e todo mundo riu dela e até ela riu. 
Observe-se que, no texto original e nas imagens, o riso de zombaria não está presente. Assim, o acréscimo feito pelas crianças certamente tem a ver com suas próprias experiências pessoais, inclusive no espaço escolar.

\section{Considerações finais}

Escolhida por ser uma composição literária interessante, com recursos humorísticos inusitados e consistindo numa narrativa polissêmica e divertida, Os chifres de Filomena (SMALL, 2003) parece ter possibilitado a recriação, por parte das crianças, de algumas estratégias de humor em seus textos escritos e imagéticos. Observa-se, por exemplo, nas produçôes analisadas, a utilização de scripts superpostos, a mescla de elementos extraordinários e situaçóes da vida cotidiana: metamorfoses de partes do corpo da personagem são apresentadas em ambientes que fazem parte da vida das próprias crianças - a escola, o shopping, a praia, o parque, entre outros. Esses deslizamentos entre o fantástico e o trivial marcam grande parte das produçóes analisadas e se manifestam tanto nos desenhos quanto nos textos escritos. Assim, pode-se pensar que a obra trabalhada pode ter motivado a utilização de recursos de humor e a utilização de diferentes scripts por parte dos pequenos leitores.

Por outro lado, destacam-se também as múltiplas metamorfoses no corpo de Filomena, imaginadas pelas crianças, e também as diferentes expressóes de um "final feliz" - a diferença que proporciona notoriedade, fama, ocasionando encontros com outros diferentes, por um lado, e a diferença que faculta à personagem experiências diversas tais como ingerir alimentos estranhos, utilizar as partes metamorfoseadas de seu corpo para adquirir agilidade nas brincadeiras ou para ajudar em tarefas domésticas, por exemplo. Pode-se supor que essa grande variação de cenários, tramas e desfechos nas produçôes das crianças também se articula com a presença do final aberto nessa narrativa literária. As surpresas, os exageros, as buscas por soluçóes vão constituindo uma espécie de jogo, no qual o leitor é envolvido e participa, imaginando também cenários e preenchendo as lacunas do texto. Relembremos, com Colomer (1999, p. 168), que

Las obras que se basan en el humor y la imaginación tienden a extender el juego con las expectativas hasta el final del cuento. Muy a menudo le dejan sonriente o soñador sin poder precisar qué ha pasado y qué no en la 
historia que acaba de terminarse. [...] En definitiva, la falta de una resolución clara de las expectativas narrativas obliga al lector a conceder una atención prioritaria al goce de otros aspectos y niveles de significado.

Assim, o jogo literário que se estende em toda a narrativa e o final aberto dificultam a instalação de sentidos fixos e homogêneos e permitem acompanhar os eventos da narrativa por distintos pontos de vista - o da protagonista, o da mãe que desmaia, o do irmão que recorre a enciclopédias, o da copeira e da cozinheira que encontram utilidades para os chifres da menina, entre outros -, e tudo isso colabora para tornar divertida a experiência do leitor com a diferença, através da literatura. Vale ressaltar, retomando a relação entre literatura, humor e diferença, que na obra Os chifres de Filomena (SMALL, 2003) a diferença não é tratada como "um problema" a ser resolvido, que envolveria os personagens em uma rede de sofrimentos a serem minimizados ou eliminados, nem como um elemento fixo, vinculado à natureza, que, portanto, demandaria uma atitude tolerante, e, sim, como um elemento que superpóe um script fantástico a outro: o do cotidiano infantil.

Fugindo ao velho modelo do narrador conselheiro e magistral, que tudo explica e a tudo atribui um significado "correto" para o pequeno leitor, a obra possibilita a produçáo de diferentes significados, a abertura ao imprevisto, ao lúdico e ao inusitado, permitindo, desta forma, releituras, composiçóes, invençóes por parte das crianças, como algumas das que foram apresentadas neste estudo.

Observando as produções verbais e imagéticas das crianças - das quais trouxemos apenas alguns exemplos -, podemos dizer que elas manifestam a dispersão de sentidos que o riso pode provocar, junto com a atualização e a transformação de experiências infantis de diversos âmbitos. Sem a pretensão de afirmar uma verdade definitiva sobre o uso de recursos humorísticos, nos parece oportuna uma reflexão feita por Lulkin $(2007$, p. 7$)$ em relação às conexóes entre humor e escola:

Se o mestre deseja a ordem rígida, o silêncio total e a fala apenas autorizada, deve manter-se longe do evento cômico, para não provocá-lo, para não autorizar a excitaçáo do riso dentro dos lugares da educação. No entanto, que o mestre não esqueça que há movimento 
nas brechas das palavras das verdades, há sempre um furo no discurso monológico, uma rachadura por onde o humor vaza.

\section{Notas}

1 A pesquisa mencionada, que dá origem ao presente artigo, denomina-se "Narrativas, diferenças e infância contemporânea" e obteve apoio do CNPq.

2 Trata-se de tradução de Imogenés Anthers, do autor estadunidense David Small, obra que, publicada em 1985, obteve grande sucesso e teve sucessivas reediçôes e traduçôes para outras línguas.

3 Os textos escritos pelas crianças tiveram sua grafia e concordância corrigidas de acordo com a norma escrita, para evitar possíveis interferências na compreensão de sua leitura.

4 Durante a exploração oral da história nas duas escolas, em relação ao desfecho do enredo, algumas crianças aventaram espontaneamente a hipótese de "tudo ter sido um sonho".

5 Trata-se de "A utilidade dos animais", constante de Carlos Drummond de Andrade (1975).

\section{REFERÊNCIAS}

ALBERTI, Verena. O riso e o risivel na história do pensamento. Rio de Janeiro: Jorge Zahar Editora, 1999.

ANDRADE, Carlos Drummond de. De notícias e não notícias faz-se a crônica. Rio de Janeiro: José Olympio, 1975.

COLOMER, Teresa. Andar entre livros. São Paulo: Global, 2007.

COLOMER, Teresa. A formaçấo do leitor literário. São Paulo: Global, 2003.

COLOMER, Teresa. Introducción a la literatura infantil y juvenil. Madrid: Síntesis Educación, 1999.

DUARTE, Lia C. Lobato humorista: a construção do humor nas obras infantis de Monteiro Lobato. São Paulo: Editora da Unesp, 2006. 
LULKIN, Sérgio. A potência do humor e do riso na escola. Alegria, n. 4, p. 1-8, 2007. Disponível em: <http://www.alegrar.com.br/04/textos_A_04/04_ riso.pdf $>$. Acesso em: 20 mar. 2010.

POSSENTI, Sírio. Os humores da língua: análises linguísticas de piadas. Campinas: Mercado de Letras, 1998.

PROPP, Vladimir. Comicidade e riso. São Paulo: Ática, 1992.

RASKIN, Victor. Semantic mechanisms of humor. Dordrecht: D. Reidel, 1985.

ROSAS, Marta. Tradução de humor: transcriando piadas. Rio de Janeiro: Lucerna, 2002.

SMALL, David. Os chifres de Filomena. São Paulo: Companhia das Letrinhas, 2003. Não paginado. 


\section{El humor en la literatura Humor in children's infantil: un estudio sobre literature: a study of reading lectura y apropiación de and the use of humor for recursos humorísticos por elementary-school children niños de los años iniciales \\ Abstract}

\section{Resumen}

El trabajo se basa en la articulación entre el campo de la literatura infantil y los estudios sobre humor e investiga las formas cómo los alumnos de los años iniciales se apropian de algunos recursos humorísticos en su propia producción textual e imaginaria, después de la realización de una actividad con una obra de literatura infantil ("Los cuernos de Imógenes", de David Small) que incorpora elementos de humor. En el estudio se aborda la cuestión del humor en la literatura infantil, se caracteriza la obra elegida, se describe el trabajo realizado y se interpreta la producción de los alumnos, identificándose, en ella, la recreación de algunas estrategias de humor. Se especula que tanto el carácter desafiador de las actividades propuestas cuanto las características de la obra, con su final abierto, pueden haber proporcionado la gran variedad de escenarios, tramas y resultados constatada en las producciones de los nińos.

Palabras claves: Diferencia. Literatura infantil. Humor.

This paper is based on the articulation between the field of children's literature and studies of humor. It investigates how elementary school students use humor in their production of text and image, after an activity with a work of children's literature that uses humor David Small's Imogene's Antlers, ['Os chifres de Filomena' in Brazil]. The study addresses humor in children's literature, characterizes the book chosen, describes the work conducted and interprets the students' production to identify how they recreate humoristic strategies. We speculate that both the challenging character of the proposed activities and the characteristics of the work, which has an open ending, may have stimulated the wide variety of scenarios, plots and denouements found in the children's productions.

Keywords: Difference. Children's literature. Humor. 


\section{Iara Tatiana Bonin}

E-mail: iara.bonin@uol.com.br

Rosa Maria Hessel Silveira

E-mail:rosamhs@terra.com.br

Recebido em: 9/3/2012

Versáo final recebida em: $15 / 11 / 2012$

Aprovado em: 19/11/2012 